\title{
Hegel's Dialectics as a Semantic Theory: An Analytic Reading
}

\author{
Francesco Berto
}

Just as when I say 'all animals', this expression cannot pass for a zoology, so it is equally plain that the words, 'the Divine', 'the Absolute', 'the Eternal', etc., do not express what is contained in them; and only such words, in fact, do express the intuition as something immediate. Whatever is more than such a word, even the transition to a mere proposition, contains a becoming-other that has to be taken back, or is a mediation.

G.W.F. Hegel, The Phenomenology of Spirit

\section{Prospect}

What is Hegel's dialectics? In 1964, Werner Flach claimed that the research on Hegel had not provided an adequate reply to this question (see Flach 1964: 55-64). More pessimistically, some years later Hans-Friedrich Fulda admitted that, despite the considerable efforts of scholars, our Auseinandersetzung with the famous Hegelian method 'has not led, so far, to any satisfactory result' (Fulda 1973: 231). In order to address such a tricky question, in this paper I expand some aspects of the current Anglo-American revitalization of Hegelian philosophy. ${ }^{1}$ My reading is based on a very simple idea: the inferential intuition that an essential part of what it is to grasp a conceptual content, and to be able to apply it correctly to an object, consists in mastering its connections with the concepts it entails, and with the concepts that entail it. ${ }^{2}$ These connections can be expressed by meaning postulates. The suggestion that Hegel's dialectics operates on meaning postulates, as far as I know, has been largely ignored by traditionalminded scholars. Nevertheless, it provides a promising path towards a new Hegel-towards a better understanding of his philosophy, and in particular of its core, the dialectical method.

It has been widely recognized that dialectics assumes as its starting point ordinary language (in the broad sense in which it includes scientific and somewhat technical philosophical terminology). In particular, it investigates the meanings of conceptual terms, shared by competent speakers and constituting their lexical competence. As Hegel says in the Preface to the second edition of the Science of Logic:

European Journal of Philosophy 15:1 ISSN 0966-8373 pp. 19-39 (C) 2007 The Author. Journal compilation (C) Blackwell Publishing Ltd. 2007, 9600 Garsington Road, Oxford OX4 2DQ, UK and 350 Main Street, Malden, MA 02148, USA. 
The forms of thought are, in the first instance, displayed and stored in human language. Nowadays we cannot be too often reminded that it is thinking which distinguishes man from the beasts. Into all that becomes something inward for men, an image or conception as such, into all that he makes his own, language has penetrated, and everything that he has transformed into language and expresses in it contains a categoryconcealed, mixed with other forms or clearly determined as such, so much is logic his natural element, indeed his own peculiar nature. $(W L: 31)^{3}$

This is the terminus a quo of dialectics. Ordinary language is theory-laden, and dialectics explicates (as we shall see, in a form very similar to the one of meaning postulates) the presuppositions and theoretical correlations that underlie the semantic settlement of conceptual terms and govern their actual use. Such an idea of a 'logical explication of the implicit' comes from Robert Brandom's works. In Making It Explicit, Brandom argues that logic should play the expressive role of the organ of semantic self-consciousness (see Brandom 1994: 384). Logical vocabulary provides the resources to express the inferential commitments articulating descriptive conceptual contents. As Brandom himself observes, the resulting structure of explanation is distinctively Hegelian (see Brandom 2000: 22). ${ }^{4} \mathrm{~A}$ few lines after the passage quoted above, Hegel says that the categories of the Logic are 'thoroughly familiar to educated people', 'determinations of thought which we employ on every occasion, which pass our lips in every sentence we speak'. Nevertheless, 'it does not follow [...] that they are intelligently apprehended'. Philosophical, or speculative, logic is the intelligent apprehension of this familiarity, the explication of this implicit or, in the Hegelian jargon, the development of the an sich in the an und für sich. A couple of pages later, we read that 'natural logic' is 'unconsciously busy' with the categories of language and thought. Speculative logic makes theoretical commitments, which are implicit in our ordinary language, explicit: 'as impulses the categories are only instinctively active', and 'the loftier business of logic therefore is to clarify these categories and in them to raise mind to freedom and truth' (WL: 36-7).

Philosophy, thus, has to begin with natural language. Hegel thoroughly opposes those authors, such as Spinoza, who start with a regimentation of it, or with stipulative definitions. But Hegel is obviously not a descriptive philosopher of ordinary language. ${ }^{5}$ For ordinary expressions can be vague, their meanings can be only partially determined and, most interesting for the dialectical procedure, the class of their synonyms can be incoherent, giving rise to inconsistencies. Therefore, philosophy also has to reshape meanings and intensional contents: it can criticize, control, and improve our linguistic business in order to introduce distinctions and rectifications where there was only confused, unconscious practice. But let Hegel say so himself-in a way one could hardly improve:

Philosophy has the right to select from the language of common life which is made for the world of pictorial thinking, such expressions as

(c) The Author 2007. Journal compilation ( B Blackwell Publishing Ltd. 2007 
seem to approximate to the determinations of the Notion. There cannot be any question of demonstrating for a word selected from the language of common life that in common life, too, one associates with it the same Notion for which philosophy employs it; for common life has no Notions, but only pictorial thoughts and general ideas, and to recognize the Notion in what is else a mere general idea is philosophy itself. It must suffice therefore if pictorial thinking, in the use of its expressions that are employed for philosophical determinations, has before some vague idea of their distinctive meaning; just as it may be the case that in these expressions one recognizes nuances of pictorial thought that are more closely related to the corresponding Notions. One will be less ready, perhaps, to admit that something can be without existing; but at least, one will hardly use 'being' as copula of the judgement as interchangeable with the expression 'to exist' and say, 'this article exists dear, suitable, etc.', 'gold exists a metal or metallic', instead of 'this article is dear, suitable, etc.', 'gold is a metal or metallic'. And surely it is usual to distinguish between being and appearing, appearance and actuality, as well as to distinguish mere being from actuality, and still more all these expressions from objectivity. However, even should they be employed synonymously, philosophy will in any case be free to utilize such empty superfluity of language for its distinctions. (WL: 708-9) ${ }^{6}$

\section{2. 'Qualitative Judgement', Inferential Commitment}

The most authoritative candidates to the role of elementary sentences in the neopositivistic tradition were those that Hegel may have called 'judgements of existence', or 'qualitative judgements' (see WL: 630-1). These are sentences in which an observational property or, in the Hegelian jargon, an 'immediate quality', is ascribed to a given individual. The example in the $\int 172$ of the Encyclopaedia is: 'The rose is red' (Enz: 249) (but something like: 'This rose is red', or simply: 'This is red', coming with a deictic act, may work equally well). It seems that such a sentence can be understood with no particular reflection or mediation. Its truth-conditions, we may say, are all here: in the gesture pointing to the red surface, in our perception of the colour. However, as Hegel observes:

It is one of the most fundamental logical prejudices that qualitative judgements such as: 'The rose is red', or: 'is not red', can contain truth. Correct they may be, but only in the restricted confines of perception, finite representation, and thinking; this depends on the content which is just as finite, and untrue on its own account. But the truth rests only on the form, i.e., on the posited Concept and the reality that corresponds to it; truth of this kind is not present in the qualitative judgement, however. (Enz: 249, \172)

(c) The Author 2007. Journal compilation ( Blackwell Publishing Ltd. 2007 
What is 'correct, but not true' in the qualitative judgement?

One of Wittgenstein's fundamental gains, in the transition from the first to the second phase of his thought, is the acquired awareness of how such candidates to the role of elementary sentences are not semantically isolated. Wittgenstein realizes that the semantics of such predicates as 'is red' was not clear to him when he wrote the Tractatus. He then claims that 'The idea of constructing elementary propositions (as e.g. Carnap has tried to do) rests on a false notion of logical analysis' (Wittgenstein 1974: 210). Wittgenstein's example in the Philosophical Grammar is nearly the same as Hegel's:

You may call the sentence 'Here there is a red rose' an elementary proposition. That is to say, it doesn't contain a truth-function and it isn't defined by an expression which contains one. But if we're to say that a proposition isn't an elementary proposition unless its complete logical analysis shows that it isn't built out of other propositions by truthfunctions, we are presupposing that we have an idea of what such an 'analysis' would be. (Ibid: 211)

But there is no such semantic analysis. It is essential that the reason for this is, in Wittgenstein's own words, that 'From "a is now red" there follows "a is now not green" and so elementary propositions in this sense aren't independent of each other' (Ibid, my italics). What Wittgenstein emphasizes in the Philosophical Grammar (as well as, e.g., in Some Remarks on Logical Form and the Big Typescript) is an inferential connection between concepts. Even the contents of those predicates that are most deeply rooted in immediate experience-typically, observational predicates standing for perceptive qualities-get determined only via relation (Vermittlung, in Hegel's jargon) with other concepts. The semantic holism coming into play here has been stressed, following Sellars, by authors like Brandom and McDowell. ${ }^{7}$ Even a parrot can be disposed to respond appropriately to the stimulation provided by a red surface to its perceptual apparatus. But we may say, following Hegel, that this has nothing to do with the concept, for it stops at the 'restricted confines of perception and finite representation'. To grasp the concept red is to know that if this surface is red, then it cannot be green; that its being red entails its having a colour; that its being red follows from its being scarlet; etc. Grasping concepts is 'knowing one's way around the properties of inference and incompatibility they are caught in' (Brandom 1994: 89).

One immediate consequence of such an inferential demarcation of the conceptual is that one must have many concepts in order to have any. For grasping a concept involves mastering the properties of inferential moves that connect it to many other concepts: those whose applicability follows from the applicability of the concept in question ['if $x$ is red, then $x$ has a colour'], those from whose applicability the applicability of the target concept follows ['if $x$ is scarlet, then $x$ is red'], those whose applicability precludes or is precluded by it ['if $x$ is red, then $x$ is not green']. One cannot have just one concept. This holism about concepts contrasts with

(C) The Author 2007. Journal compilation (C) Blackwell Publishing Ltd. 2007 
the atomism that would result if one identified concepts with differential responsive dispositions. (Ibid)

Brandom clearly ascribes such an inferential holism, not only to Sellars, but also to Hegel. ${ }^{8}$ The rest of this paper aims at showing why such an ascription is quite correct.

According to Hegel, inferential connections come into play, first of all, in what he calls 'the judgement of reflection'. The determination of the content of such a kind of sentences requires reference to the content of many other sentences, since properties, or concepts, ${ }^{9}$ that come into play here are mediated ones:

In the judgement that has now arisen [...] the universal is no longer an abstract universality or a single property, but is posited as a universal that has gathered itself together into a unity through the relation of distinct terms; or, regarding it from the point of view of the content of various determinations in general, as the taking together of various properties [...]. Predicates of this peculiar kind [...] express an essential determination, but one which is in a relationship or is a unifying universality. (WL: 643)

The example given in the Zusatz of $\int 174$ of the Encyclopaedia Logic is: 'This plant is curative' (Enz: 252). The property of being curative, of course, is not perceptually given via instant observation of the plant. We can say truly that the plant is curative, because it has some other specific property (e.g., that of having purified wounds to which it has been applied), whose possession makes the inference to the more abstract concept curative legitimate-that is to say, in Hegelian terminology, it mediates the application of the latter concept to the plant. Further examples provided in the Major Logic are: 'This thing is useful', 'This thing is harmful', and the evergreen: 'Man is mortal' (see WL: 643).

\section{Semantic Ascent and Material Inference: the Hegelian Schema}

According to Fulda, most of the strictly theoretical sentences of the Logic have the form: 'der (die, das) $t_{1}$ ist der (die, das) $t_{2}$ ' (or: 'der (die, das) $t_{1}$ ist $t_{2}$ ') (See Fulda 1973: 252). This I shall call the Hegelian Schema. ' $t_{1}$ ' and ' $t_{2}$ ' can be substituted in it by variously shaped abstract or general terms: abstract common nouns like 'Difference' (Differenz), 'Reflection' (Reflexion), 'Limit' (Grenze); nominalized adjectives or verbs like 'Becoming' (Werden), 'Being' (Sein), 'Infinite' (Unendliche); compound expressions like 'Being-for-other' (Sein-für-Anderes); etc. The important point is that such expressions always stand for concepts: 'the $t_{1}$ ' (e.g. 'the Ideal') is a short form for: 'the concept $t_{1}$ ' ('the concept Ideal'), or: 'the concept called " $t_{1}$ "', ('the concept called "Ideal"').

If Fulda is right, then Hegel's logic constantly speaks to us about conceptual relations. Some examples from the first chapters of the Logic: 'Reality [...] is determinate being' (Die Realität [...] ist Dasein) (WL: 115); 'Being-for-other is [...]

(C) The Author 2007. Journal compilation (C Blackwell Publishing Ltd. 2007 
a negation of the simple relation of being to itself' (Das Sein-für-Anderes [...] ist [...] Negation der einfachen Beziehung des Seins auf sich) (WL: 120); 'Ideality [...] is [...] the process of becoming' (Die Idealität [...] ist [...] der Prozess des Werdens) (WL: 150). Further examples from the Encyclopaedia: 'Measure is qualitative quantum' (Das maß ist das qualitative Quantum) (Enz: 170, \107); 'Essence [is] being that has gone into itself' (das Wesen das in sich gegangene Sein ist) (Enz: 175, \$ 112); 'What exists is thing' (ist das Existierende Ding) (Enz: 193, \ 124). Taking into account such concepts by expressing their inferential relations with other concepts is, according to the Hegelian strategy, the duty of philosophical or speculative logic as 'the organ of semantic self-consciousness'. And since concepts used in ordinary language to talk about objects become themselves the object of speculative logic, what we have here is some sort of semantic ascent.

In Word and Object, Quine calls 'semantic ascent' the move from talking in certain terms to talking about them-for instance, the shift from talk of miles to talk of 'mile'. In the following, I shall give the locution a much more realistic flavour: it expresses our coming to make reference to (quantify over, etc.) things of a higher order than the ones we started with. Typically, it is the move from talking about individual objects falling under concepts (e.g. about Socrates, who is a man), to talking about concepts (the concept man) under which objects fall. This is particularly clear in many steps of the Logic. For instance, talking about the concept something in the chapter devoted to Determinate Being, Hegel says that 'in our ordinary way of thinking, something is rightly credited with reality' (Etwas gilt der Vorstellung mit Recht als ein Reelles). But he immediately adds: 'however, something is still a very superficial determination' (Etwas ist noch eine sehr oberflächliche Bestimmung) (WL: 115). In the first occurrence of 'Etwas', reference is made to something having a certain importance for the Vorstellung. The second occurrence, though, clearly points to the concept something. Speculative logic produces a semantic ascent with respect to everyday language. Common language uses such expressions as 'Etwas' to make generic reference to the things of ordinary experience. Philosophical logic assumes as an object of reference and theoretical consideration the concept something, das Etwas.

Further exploration of Hegel's theory of judgement ${ }^{10}$ can help us understand how such a semantic ascent takes place. As a first instance of the 'der $t_{1}$ ist $t_{2}$ ' schema, let us take the example of a judgement of reflection proposed in the Logic:

\section{Man is mortal}

(see WL: 643). When we assert (1), we do not ascribe a property (that of being mortal) to a concept (the concept man). To use a Fregean jargon: we do not assert that this concept immediately falls under a higher order one-as it would be if we said something like:

(2) The concept man is a concept which has changed in the course of history.

Human beings, not concepts, are mortals, even though concepts can change in the course of history. According to the usual paraphrase, what we are saying by asserting (1) is:

(c) The Author 2007. Journal compilation ( Blackwell Publishing Ltd. 2007 
(3) All men are mortal.

But if 'all men' appears in (3) as the grammatical subject, such a kind of subject disappears in the standard, Fregean analysis of quantified sentences. What we have is universal quantification on a sentential function with the shape of a conditional:

$$
\forall x(H(x) \rightarrow M(x)),
$$

and, as Frege says in Concept and Object,

It is to be observed, that the words 'all', 'every', 'not any', 'some', stand in front of words denoting concepts. In the general and particular, affirmative and negative sentences we express relations between concepts, and we point to the particular kinds of such relations through those words ... (Frege 1892: 172, my italics)

If, as Frege observes, here we are expressing relations between concepts, then by saying that all men are mortal we highlight some relation between the concept man and the concept mortal. Now, in his treatment of the last form of the judgement of reflection-which is exactly the universal judgement-Hegel cheerfully concedes that the grammatical shape of such a kind of sentence has to do with a set of individuals (today we may say: the objects in the domain of quantification). What is implicitly in question here, though, is a relation between concepts:

Universality, as it appears in the subject of the universal judgement, is the external universality of reflection, allness: 'all' means all individuals, and in it the individual remains unchanged. This universality is, therefore, only a taking together of independently existing individuals [...]. But there is, here, a vague awareness of the true universality of the Notion; it is the Notion that forces its way beyond the stubborn individuality to which unphilosophical thinking clings and beyond the externality of its reflection, substituting allness as totality [...]. Therefore this reflection, which extends individuality to allness, is not external to it; on the contrary, this reflection merely makes explicit what it already is in itself. Hence the result is in truth objective universality. The [grammatical] subject has thus stripped off the form determination of the judgement of reflection which passed off from this [i.e. the singular sentence], through some [i.e. the particular sentence, like 'some men are bald'] to allness; instead of all men we have now to say man. (WL: 647-9)

Hegel is inviting us to perform some sort of intensional semantic ascent: just as there is, to adjust Quine's example, an ascent from talk about miles to talk about the mile; so there is an ascent from talk about something, Etwas, to talk about the concept something, das Etwas, from talk about men to talk about man, etc. Unlike Quine, though, Hegelian ascent entails ontological commitment to

(C) The Author 2007. Journal compilation (C Blackwell Publishing Ltd. 2007 
some sort of conceptual realism. ${ }^{11}$ As Hegel says, 'What belongs to all the individual of a genus belongs to the genus by its nature', so that 'the subject, for example all men, strips off its form determination, and man is to take its place' (WL: 650). So, it is sentence (3), saying that all individuals belonging to the species man have the property of being mortals, that becomes an assertion concerning the species, in the sense that it exposes an inferential relation between the concept man and the concept mortal. Such a semantic ascent, being of an intensional kind (not into sets, but into concepts), reverses the inclusion relation: extensionally, to say that all men are mortal is to say that the set of men is a (proper) subset of, that is to say, it is included in, the set of mortals. But when we come to talk of the concept man, it is this concept that includes, as its conceptual note or semantic aspect, some reference to the concept mortal - the reference given by the inferential commitment that that sentence makes explicit. ${ }^{12}$

These conceptual relations are the prime matter and the starting point of Hegel's dialectics as a holistic semantic theory. Conceptual contents are determined insofar as they entertain various relations with other contents. Knowledge and mastery of such relations constitutes (the inferential aspect of) lexical competence. ${ }^{13}$ And dialectical process, as we know, makes these holistic connections between meanings explicit. Such a treatment is not very different from the one commonly provided by any textbook of semantics for ordinary language: the one via meaning postulates, which are exactly modal implicative, or implicative-negative, sentences.

The copula 'ist' in the sentences instantiating the Hegelian Schema 'the $t_{1}$ is (the) $t_{2}$ ' expresses a reflexive, transitive but non-symmetric relation. Reflexivity is what Hegel obviously finds less interesting, not to say disappointing, because it does not provide any further determination of the involved concept. To say that man is ... man, contradicts the promise of propositional connection in general: 'a proposition promises a distinction between subject and predicate', but 'the identity-proposition does not furnish what its form demands' (Enz: 180, \ 115). Nevertheless, we sometimes find in Hegel's writings such expressions as the subjective [...] is merely subjective' (Enz: 289, \214), or 'the finite [...] is only finite' (das Endliche ist nur das Endliche) (WL: 130). This happens precisely in those contexts, in which Hegel criticizes the abstracting Verstand. The Understanding is, typically, the kind of thought which seems unable to proceed beyond the isolated concept by grasping its relations with other concepts. ${ }^{14}$

Transitivity of the relation emerges from the fact that many Hegelian arguments have the form of the schema: 'if the $t_{1}$ is (the) $t_{2}$, and the $t_{2}$ is (the) $t_{3}$, then the $t_{1}$ is (the) $t_{3}{ }^{\prime}$ (we shall look at some instances of this schema in the following, when we shall discuss Hegel's shift from the judgement to the syllogism). That the relation is not symmetric, finally, is clearly exhibited by Hegel's rejection of the mere reversibility of subject and predicate. In his treatment of the speculative judgement in the Preface of the Phenomenology of Spirit, he points out that, when we say 'The actual is the universal' (das Wirkliche ist das Allgemeine)—which is obviously nothing but an instance of the the $t_{1}$ is (the) $t_{2}{ }^{\prime}$ schema-'das Allgemeine' is not just a different name for the same concept

(C) The Author 2007. Journal compilation (C) Blackwell Publishing Ltd. 2007 
designated by 'das Wirkliche'. On the contrary, 'the universal is meant to express the essence of the actual' (Phän: 39), that is to say, 'the universal' stands for an internal determinacy, or a necessary conceptual note, of the concept actual. ${ }^{15}$ And even though the predicate expresses-at least, insofar as speculative sentences are concerned-something essential to grasp the meaning of the subject, this is not to legitimate perfect synonymy between the two involved conceptual terms.

Now, these formal properties of the relation expressed by the 'ist' of the Hegelian Schema are exactly those of entailment. Entailment is a reflexive and transitive, but not symmetric, relation. And a conditional is the logical symbol we use to make conceptual entailments explicit via meaning postulates. A part of the lexical competence an English speaker needs, in order to understand the meaning of the word 'man', and to correctly apply the predicate '... is a man', is the commitment to such an entailment as the one expressed by (4). One knows what it means to say that something is a man-i.e. the word 'man' has a fixed meaning for her-only insofar as she knows the semantic connections that link that conceptual content to others; for instance, to the concept mortal. Since Carnap, though, meaning postulates are understood as modal assertions. For instance, a part of the implicit shared meaning of the word 'father' can be made explicit by exhibiting the inferential connections of the relation ... is the father of - as follows (with $M, W, P$ standing, respectively, for the properties of being a male, a woman, and the parent-son relation):

$$
\begin{aligned}
& \square \forall x \forall y(F(x, y) \rightarrow M(x)) \\
& \square \forall x \forall y(F(x, y) \rightarrow \neg W(x)) \\
& \square \forall x \forall y(F(x, y) \rightarrow P(x, y))
\end{aligned}
$$

Necessarily, whoever is someone's father, is a male, is not a woman, is someone's parent. Meaning postulates can be understood in model-theoretic semantics (typically, possible worlds semantics) as restrictions on admissible models, that is to say, formulas of the language that are supposed to be true in all acceptable interpretations. This means that their semantic role is to exclude some interpretations: to assume on the basis of the shared lexical competence that necessarily no married man is a bachelor, is to accept only interpretations that assign to ' . . is a bachelor' and ' . . is a married man' separate extensions in all worlds of the model. To accept (6) is to exclude that in some world someone is both a father and a woman. Semantic connections implicit in the understanding of the meaning of words like 'bachelor', 'mother', or 'woman', are made explicit, via the elementary logical vocabulary (sentential connectives and quantifiers), in such expressions as (5)-(7).

Such a procedure is closely related with what Brandom calls, following Sellars, 'material inference'. ${ }^{16}$ The usual notions of validity, logical consequence, etc., concern all interpretations, and in this sense they are formal, basing themselves only upon logical vocabulary. Meaning postulates express inferences, entailments and consequences involving non-logical content of descriptive vocabulary. ${ }^{17}$ They do it by imposing restrictions on the semantic interpretation: one cannot

(C) The Author 2007. Journal compilation (C) Blackwell Publishing Ltd. 2007 
claim to have access to the shared meaning of 'father', if she applies to something the concept father, while refusing to apply to that very thing the concept parent too. This is forbidden by postulate (7). On this basis, it is easy to define a notion of semantic consequence as logical consequence restricted to the admissible models, i.e. to those that are not excluded by the postulates.

The procedure of semantic determination expressed by inferential connections between concepts holds in general for the meaning of conceptual words. It holds, thus, in particular for the categories of thought, the 'pure essences' Hegel's logic deals with. The 'semantic self-consciousness' produced by speculative logic consists, first of all, in illuminating the intensional content of conceptual terms expressing such categories (terms like 'Determinate being', 'Something', 'Beingfor-other', 'Essence', 'Limit', etc.), via the intensional content of other terms, that is to say, by making the holistic relations between the involved meanings explicit through expressions of the form 'the $t_{1}$ is (the) $t_{2}$ '. Such expressions constitute partial determinations of the concepts at issue: to say that the $t_{1}$ is (the) $t_{2}$ is to say that the intension of ' $t_{2}$ ' is a semantic constituent of the intension of ' $t_{1}$ ': an essential conceptual note of the concept $t_{1}$, which is thus to be considered (and, if it is the case, reconsidered) in terms of the concept ' $t_{2}$ ' stands for, and to which is now inferentially connected. We gain a partial determination of the concept essence, when we are told that it is the completed return of being into itself (WL: 390). We also deepen our understanding of the concept being, as opposed to essence, when we learn that essence is the truth of being ( $W L: 389$ ). We are supposed to know something more about the concept ideality, when we understand that (and why) it is the process of becoming. We get closer to such a generic notion as the one of thing (Ding), when we know that it is nothing but what exists in general (Enz: 193, \124).

\section{Dialectical Negation, Material Incompatibility}

Such an approach to dialectics as a semantic theory can help us understand why, in the exposition of his dialectical method, Hegel claims that its essence is embedded in a certain concept of negation: the one according to which the negation is a specific negation, it has a content'. More than this, the 'quite simple insight' of 'the logical principle that the negative is just as much positive' (See WL: 54), is all we need in order to understand dialectics. Let us see why.

The postulates of modern model-theoretic semantics are the inheritors of the expressions instantiating the Hegelian Schema 'der (die, das) $t_{1}$ ist der (die, das) $t_{2}{ }^{\prime}$, or 'der (die, das) $t_{1}$ ist $t_{2}{ }^{\prime}$, by which speculative logic inferentially articulates the meanings of conceptual terms. But the most important semantic idea of Hegel's dialectics involves the determination of concepts via modally qualified relations of exclusion. These relations can be expressed by modal implicativenegative statements: sentences asserting that, if something instantiates a given concept, then it cannot instantiate some other. Such a kind of relation between

(C) The Author 2007. Journal compilation $\odot$ Blackwell Publishing Ltd. 2007 
the meanings of conceptual terms exhibits the Hegelian idea of determinate negation, a deeply intensional notion. As Brandom has observed:

Hegel's two central semantic concepts in the Phenomenology are both inferential notions. 'Mediation', his term for inferential articulation, is derived from the role of the middle term in syllogistic inference. 'Determinate negation' is his term for material incompatibility, from which, he takes it, the notion of formal negation is abstracted. (Brandom 1994: 92)

We will consider mediation (Vermittlung) in the next section. Let us concentrate now on material incompatibility, and the abstraction of formal (i.e. regular logical) negation from it. According to Hegel, the determinacy of the world is expressed via predication, ascription of properties to things. But any predication has a determinate content only insofar as it entails the exclusion that the thing $x$, to which some property $P_{1}$ is ascribed, has some other property $P_{2}$ : omnis determinatio est negatio. We can say, then, that the relation of material incompatibility holds between properties $P_{1}$ and $P_{2}$. Let us label material incompatibility with a symbol logicians know very well: ' $\perp$ ' ( $\perp$ is obviously supposed to be symmetric, i.e. if $P_{1} \perp P_{2}$ then $P_{2} \perp P_{1}$ ). Very small fine-tunings would equally allow us to express it in terms of concepts, states of affairs, or worlds, depending on one's metaphysical preferences. For instance, we may say that material incompatibility holds between two concepts $\mathrm{C}_{1}$ and $\mathrm{C}_{2}$, if and only if the very instantiating $C_{1}$ by $x$ excludes the possibility that $x$ also instantiates $C_{2}$, and vice versa. Or we may say that it holds between two states of affairs $\mathbf{s}_{1}$ and $\mathbf{s}_{2}$, if and only if the holding of $\mathbf{s}_{1}$ (in world $w$, at time $t$ ) precludes the possibility that $\mathbf{s}_{2}$ also holds (in world $w$, at time $t$ ), and vice versa. $\perp$ is thus a deeply metaphysical notion: it is rooted in our experience of the world, not only in semantics or pragmatics. It is also a strongly modal one: material incompatibility does not hold between two merely different properties, like being red and being circular, which can be instantiated by the same object, even though sometimes they are not. It holds between two properties, such that an object instantiating one of them has dismissed any chance of simultaneously instantiating the other, like being circular and being square.

Now, according to Hegel something is a determinate being, a Dasein or bestimmtes Sein (not the empty Sein, which is nothing but Nichts), only insofar it has properties, or falls under concepts. But that something has some property is itself a determinate state of affairs only insofar as its holding excludes the holding of other states of affairs. This in turn entails the determinacy of the property, or of the concept, which is obtained via relations of strongly modal material incompatibility with other concepts, or properties. To say that $x$ has some property $P_{1}$ is to say something with a determinate content, and something informative with respect to $x$, only insofar as such a predication entails the exclusion of the possibility that $x$ has some other, itself determined, property $P_{2}$.

(c) The Author 2007. Journal compilation ( B Blackwell Publishing Ltd. 2007 
This 'other' property $P_{2}$ is, according to Hegel, a determinate negation (bestimmte Negation) with respect to $P_{1}$.

We said that meaning postulates holistically articulating the content of concepts can be seen as restrictions on admissible models. For instance (with $M$, $S, D, O$, standing respectively for the properties of being a man, a stone, a dog, an oviparous):

$$
\begin{aligned}
& \square \forall x(M(x) \rightarrow \neg S(x)) \\
& \square \forall x(M(x) \rightarrow \neg D(x)) \\
& \square \forall x(M(x) \rightarrow \neg O(x)) .
\end{aligned}
$$

So, not only being a man entails being mortal; but also, being a man excludes being a dog, a stone, an oviparous. And knowledge of (8)-(10) is a part of what it is to grasp the concept man. What is so special, then, with dialectical negation as determinate negation, with respect to standard negation? In his treatment of negative judgement in the Logic, Hegel maintains that the mere contradictory of a concept is not the kind of thing that can help us grasp the concept itself:

If we stick to the negative in the completely abstract determination of immediate non-being, then the predicate is only the completely indeterminate not-universal. This determination is commonly treated in logic in connexion with contradictory notions and it is inculcated as a matter of importance that in the negative of a notion one is to stick to the negative only and it is to be regarded as the merely indeterminate extent of the other of the positive notion. (WL: 638)

The mere negation (bloße Negation), or contradictory, of a concept is what we obtain, via abstraction, from the concepts which constitute determinate negations of (i.e. are materially incompatible with) that concept. For instance:

$$
\begin{aligned}
& \square \forall x(S(x) \rightarrow \neg M(x)) \\
& \square \forall x(D(x) \rightarrow \neg M(x)) \\
& \square \forall x(O(x) \rightarrow \neg M(x)) .
\end{aligned}
$$

Necessarily, if something is a stone, a dog, an oviparous, it is not a man. Possession of any of those properties prevents the chance that $x$ has the property of being a man (or, equally: falling under one of the concepts stone, dog, oviparous, prevents the chance of falling under the concept man). The generic contradictory of the concept man, or the 'mere negation' of the fact that $x$ has the property of being a man, can thus be defined in the inferential framework as the minimal incompatible notion with respect to man: it is that which follows from all that is materially incompatible with man. It is, thus, the result of an abstraction from all the relations of material incompatibility that hold between a property and the properties that constitute determinate negations of it, in the sense that it is entailed by any of them. So, if we only considered the opposition between man

(C) The Author 2007. Journal compilation (C) Blackwell Publishing Ltd. 2007 
and not man, that is to say, if this were for us the only connection the concept man entertained, according to Hegel it would be an empty notion:

In the doctrine of contradictory concepts, one concept is, for instance, called blue [...], the other not-blue, so that this other would be not an affirmative (like, for instance, yellow), but is just the abstractly negative that has to be held fast. That the negative is also positive within itself [...] is already implied in the determination that that which is opposed to another is its other. (Enz: 185-6, \119)

Conversely, it is because the concept man entertains relations of material incompatibility with several other concepts, that we can derive, via abstraction, its formal negation or contradictory. Such incompatibility is labelled material exactly to stress the fact that it is not a merely logical, in the sense of formal, notion: it is based on the material content of the involved concepts. So, Hegel would probably endorse Huw Price's claim:

The apprehension of incompatibility [is] an ability more primitive than the use of negation. The negation operator is being explained as initially a means of registering (publicly or privately) a perceived incompatibility. [...] For present purposes, what matters is that incompatibility be a very basic feature of a speaker's (or proto-speaker's) experience of the world, so that negation can plausibly be explained in terms of incompatibility. (Price 1990: 226-8)

As a matter of fact, definitions of formal negation via material incompatibility are quite frequent in contemporary logic. For instance, here is an account which adapts the idea, proposed by J.M. Dunn, that 'one can define negation in terms of one primitive relation of incompatibility [...] in a metaphysical framework' (Dunn 1996: 9). Dunn refers to the Birkoff-von Neumann-Goldblatt definition of ortho negation, a notion originally developed within quantum logic. What makes this characterization interesting is that it uses precisely a relation of incompatibility (also called 'orthogonality', or simply 'perp': see Birkoff and von Neumann 1936, Goldblatt 1974). Take an ordered couple $\langle S, \perp>$, where $S$ is a set of properties, and $\perp$ is our binary relation of material incompatibility, defined on $S$. Then we have:

$$
\left(\mathrm{Df}_{\neg}\right) \neg P_{1}(x)=_{\mathrm{df}} \exists P_{2}\left(P_{2}(x) \wedge P_{1} \perp P_{2}\right) .
$$

To say that something is not $P_{1}$ is to say that it has some property $P_{2}$, which is materially incompatible with respect to $P_{1}$. Such a partial indeterminacy in the information conveyed by an expression containing 'not' reflects a very simple fact of ordinary language. When we say 'The car is red', this is not the weakest, or less informative, sentence incompatible with the sentence 'The car is blue'. The weakest sentence incompatible with 'The car is blue' is 'The car is not blue', which, given $(\mathrm{Df} \neg)$, merely says that the car has some other (materially

(C) The Author 2007. Journal compilation (C Blackwell Publishing Ltd. 2007 
incompatible) property than that of being blue, not specifying which one. 'The car is red' specifically says which other, incompatible colour the car has. ${ }^{18}$

Now, Hegel undoubtedly endorsed the expressive instance according to which the content of conceptual terms has to be made explicit via inferential relations of material incompatibility. Among the many places in his works making this point, we may consider the chapter dedicated to Perception in the Phenomenology of Mind. Here, Hegel clearly maintains that a determinate world cannot be articulated via relations of mere (gleichgültige) difference: it has to develop into exclusive (ausschließende) differences, that is to say, determinate negations.

At the end of the chapter dedicated to Sense Certainty, we overcome the idea that the things of our experience are immediate data of senses. Perceptive consciousness assumes its object, then, as an individual which is not a bare particular, but something falling under concepts, having properties. The thing is what unifies the many properties it has:

Since the principle of the object, the universal, is in its simplicity a mediated universal, the object must express this its nature in its own self. This it does by showing itself to be the thing with many properties. [...] Consequently, the sense-element is still present, but not in the way it was supposed to be in [the position of] immediate certainty: not as the singular item that is 'meant', but as a universal, or as that which will be defined as a property. (Phän: 68)

Now, Hegel adds, perceptive consciousness in the beginning tends to conceive the properties as 'related [only] to themselves [...] indifferent to one another, each on its own and free from the others':

This salt is a simple Here, and at the same time manifold; it is white and also tart, also cubical in shape, of a specific gravity, etc. All these many properties are in a single simple 'Here' [...]. And, at the same time, without being separated by different Heres, they do not affect each other in this interpenetration. The whiteness does not affect the cubical shape, and neither affects the tart taste, etc.; on the contrary, since each is itself a simple relating of self to self it leaves the others alone, and is connected with them only by the indifferent Also. (Phän: 68-9)

But now, dialectics demands that properties are themselves articulated via relations of determinate negation, or material incompatibility with respect to other properties. The thing is a bestimmtes Sein insofar as it is an exclusive core with respect to concepts materially incompatible with the ones it instantiates. Thus, the initial idea of perception, aiming to describe the thing through a mere conjunction of sentences attributing to it its properties (the 'indifferent Also') has to be aufgehoben:

If the many determinate properties were strictly indifferent to one another, if they were simply and solely self-related, they would not be

(C) The Author 2007. Journal compilation (c) Blackwell Publishing Ltd. 2007 
determinate; for they are only determinate in so far as they differentiate themselves from one another, and relate themselves to others as to their opposites. Yet; as thus opposed to one another they cannot be together in the simple unity if their medium, which is just as essential to them as negation; the differentiation of the properties, in so far as it is not an indifferent differentiation but is exclusive, each property negating the others, thus falls outside of this simple medium; and the medium, therefore, is not merely an Also, an indifferent unity, but a One as well, a unity which excludes an other. (Phän: 69)

\section{Vermittlung and Syllogism}

According to the Encyclopaedia, 'Every thing is a judgement.-That is, every thing is a singular, which is inwardly a universality or inner nature, in other words, a universal that is made singular' (Enz: 246, \ 167). This means, as we know, that things are not bare particulars insofar as they have properties: they are objects ('singulars') falling under concepts ('universalities'). But concepts themselves are determinate concepts because of their inferential relations of entailment and material incompatibility with other concepts. This means that conceptual contents expressed by a sentence can be determinately grasped only insofar as they are linked to many other conceptual contents, expressed by other sentences. We make such relations explicit by taking into account entailments in which ordinary reasoning is articulated. Hence comes the Hegelian idea that 'The truth of the judgement is the syllogism' (WL: 672). Just like, according to Brandom's dictum, one cannot have exactly one concept, so according to Hegel one cannot grasp anything meaningful through exactly one sentence. This emerges particularly in the last kind of judgement considered both in the Major Logic and in the Encyclopaedia Logic: the judgement of the notion. Here the route to syllogism is provided by a form, the apodictic judgement, which contains some sort of internal inference.

Assertoric judgement as such-for instance: 'This house is good'-stands in need of justification: as Hegel says, 'accordingly [...] is confronted with equal right by its contradictory'. It is a mere assurance, it 'is therefore essentially problematic' (WL: 660). But it finds its foundation by being developed into the apodictic judgement: 'This — the immediate singularity-house-the genus-being constituted so and so-particularity-is good or bad' (Enz: 256, \179). Here 'being constituted so and so' is the middle term, grounding or, as we may say, mediating the application of the concept good to this house, on the basis of an implicit pattern: if a house is constituted so and so (for instance, following certain criteria or construction, using certain stuff, etc.), then it is a good house; but this house is constituted so and so; therefore, it is a good house.

We observed that the conceptual relation expressed by the Hegelian Schema 'der (die, das) $t_{1}$ ist der (die, das) $t_{2}$ ' is a transitive one. Hegel often emphasizes

(c) The Author 2007. Journal compilation ( Blackwell Publishing Ltd. 2007 
the role of the middle term in inferences of the form 'if the $t_{1}$ is (the) $t_{2}$, and the $t_{2}$ is (the) $t_{3}$, then the $t_{1}$ is (the) $t_{3}$. They often turn into: 'the $t_{1}$ is, as $t_{2}$, the $t_{3}$ ' (for instance: "The continuity of the property $[\ldots]$ is, as this negative unity, the restored something of thinghood' WL: 492); or: 'the $t_{1}$, which is determined as the $t_{2}$, is the $t_{3}{ }^{\prime}$ (for instance: '[The] thing, which has determined itself as the merely quantitative connexion of free matters, is the simply alterable thing', WL: 494). The paradigm of Vermittlung is the middle term of the syllogism. This helps us see why, according to the Encyclopaedia, we should not just say that 'Every thing is a judgement', but also that 'Everything is a syllogism' (Alles ist ein Schluß) (Enz: $257, \llbracket 181)$. It is thus clear that the notion of Vermittlung has to do with the inferential movement through concepts. Hegel characterizes it this way in the Introduction of the Encyclopaedia:

Mediation is a beginning, and a having advanced to a second, in such a way that this second is only there because one has come to it from something that is other vis-à-vis this second. (Enz: 36, \12)

But the Hegelian notion of mediation is clearly connected with the one of determinate negation, too. Relations mediating concepts with each other are first of all those of material incompatibility, or reciprocal modally qualified exclusion: the concept which is 'mediated' is determined via another concept, which is its determinate negation. As Brandom observes, schließen, the passage into the conclusion of the syllogistic inference, is rooted in ausschließen, exclusion (see Brandom 2001). Determination of objects via predication, ascription of properties which manifests itself in the judgement, passes into determination of properties via inferential relations between judgements, which manifests itself in the syllogism. And such a determination has as its essential proper part the intensional exclusions, the relations of determinate negation between materially incompatible properties, or concepts: conclusion is rooted in exclusion, because determinatio est negatio.

Finally, determinacy of the meaning of conceptual terms, just like their mastery, is a matter of degree. As Brandom observed, according to the inferential semantics mastery of a propositional content is not an all-or-nothing situation. This holds both for the metaphysical concepts Hegel's logic investigates, and for ordinary and empirical concepts. The degree of individuation of a concept may vary on the basis of the different kinds of linguistic competence; that is to say, on the basis of the number and variety of the inferential connections and meaning postulates of which the speaker is conscious. Hegel would probably have endorsed the idea that the meanings of our general, conceptual terms, like ' $m^{2}$ ', 'tiger', 'elm', 'beech', 'essence', 'appearance', is determined within our shared theories. He would also have added that awareness of this is the peculiarly philosophical aspect of the story. It is this awareness that assigns a non-arbitrary place to the various productions of the Geist. And the acquisition of such awareness is the duty of speculative logic or, better, 'the loftier business of logic'.

(C) The Author 2007. Journal compilation @ Blackwell Publishing Ltd. 2007 
As Nelson Goodman once said, 'The practical scientist does the business; but the philosopher keeps the books' (Goodman 1972: 168).

\author{
Francesco Berto \\ University of Padua \\ Department of Philosophy \\ Piazza Capitaniato, 3 \\ 35139 Padova \\ Italy \\ francescoberto@tin.it
}

\section{NOTES}

1 Such a revitalization is rooted in Wilfrid Sellars' Empiricism and the Philosophy of Mind, unfolded in John McDowell's justly celebrated Mind and World, and Robert Brandom's works-but see also, e.g. Lamb 1979 (which anticipates much of the current rediscovery of Hegel as a critic of the Myth of the Given), Pippin 1988, Pinkard 1994, Redding 1996. McDowell presents Mind and World as 'A prolegomenon to a reading of Hegel's Phenomenology' (McDowell 1994: ix). My primary debts in this paper, though, are towards Robert Brandom's inferential semantics, as we shall see in the following.

2 This bi-dimensional account of content, given in terms of circumstances/ consequences of application, extends to descriptive vocabulary Gentzen's inferential treatment of logical vocabulary via introduction/elimination rules in natural deduction (see e.g. Dummett 1973).

${ }^{3}$ See the closing References for the abbreviations of Hegel's works. Page numbers always refer to the English translations listed in the References.

4 As V. Hösle observed in a recent comparison of Brandom and Hegel, 'For Brandom as for Hegel logic is more than the elaboration of a consistent system of axioms; philosophical logic must aim at a justification of the fundamental logical locutions, it must clarify the relation between concepts, propositions and inferences, it must be, to quote Brandom again, "the linguistic organ of semantic self-consciousness and self-control"" (Hösle 2003: 307-8).

5 As Jaeschke 1979 and Schnädelbach 1999, for instance, have forcefully stressed. I have argued at length on this point in Berto 2005: Chs. 1 and 8.

6 According to Y. Yovel, Hegel's enterprise aims at 'creating a new philosophical glossary by exploiting existing ambiguities and connotations of ordinary language. In declaring this program [...], Hegel specifically offers to make systematic distinctions between terms that are usually considered to be synonyms, especially the set: Existenz, Dasein, Wirklichkeit, etc.' (Yovel 1981: 117).

${ }^{7}$ Let us listen to McDowell's version in Mind and World: 'For example, consider judgements of colour. These judgements involve a range of conceptual capacities that are as thinly integrated into understanding of the world as any. Even so, no one could count as making even a directly observational judgement of colour except against a background sufficient to ensure that she understands colours as potential properties of things. The ability to produce "correct" colour words in response to inputs to the visual system (an ability possessed, I believe, by some parrots) does not display possession of the relevant concepts if the subject has no comprehension of, for instance, the idea that these responses

(C) The Author 2007. Journal compilation C Blackwell Publishing Ltd. 2007 
reflect a sensitivity to a kind of state of affairs in the world, something that can obtain anyway, independently of these perturbations in her stream of consciousness. The necessary background understanding includes, for instance, the concept of visible surfaces of objects and the concept of suitable conditions for telling what colour something is by looking at it (McDowell 1994: 12).

8 'One of the most important lessons we can learn from Sellars's masterwork, "Empiricism and the Philosophy of Mind" (as from the "Sense Certainty" section of Hegel's Phenomenology), is the inferentialist one that even such noninferential reports must be inferentially articulated. Without that requirement, we cannot tell the difference between noninferential reporters and automatic machinery such as thermostats and photocells, which also have reliable dispositions to respond differentially to stimuli' (Brandom 2000: 48-9).

9 Throughout this paper, I always use 'concept' and 'property' as synonymous. This can be settled semantically via a Fregean account: a predicative term expresses a sense and, by virtue of it, it stands for a concept. Concepts, thus, belong to the level of reference: they are something general, or universal, just as properties are supposed to be within ontological realism: something we can speak of and quantify over. That this was Hegel's position is quite clear. Hegelian idealism takes concepts to be objective and real, not at all abstractions whose only home would be within our heads. Among the many passages in Hegel's works that argue for this point, it may suffice, for instance, to have a look at the $\int$ 162 of the Encyclopaedia Logic, with its complaint against 'what is usually understood by "concepts"', that is to say, 'just general notions'. On the contrary, concepts are 'the living spirit of what is actual; and what is true of the actual is only true in virtue of these forms, through them and in them' (Enz: 238-9, \ 162).

${ }^{10}$ The importance of Hegel's theory of judgement in his Doctrine of the Concept has been stressed by Theunissen, who considers the copula 'ist' of the Hegelian Schema exactly as the operator of conceptual mediation (see Theunissen 1980: 46 and 80).

${ }^{11}$ That the language of Hegel's dialectics is typically committed to such a form of abstraction or semantic ascent, is argued, among others, in Barth 1981: 58ff. A similar position is held in J.N. Findlay's works, e.g., Findlay 1958. See also Findlay 1981: 132: 'Dialectical reasoning in short involves that genuine passage beyond premises that is also involved in passing from an object-language to a meta-language that disposes of richer resources, and in which, though the conclusion is in a sense implied by the premises, it is not implied by them in the straightforward sense in which "Either not-p or $r$ " is implied by the conjunction of "Either not-p or q" and "Either not-q or $r$ ".

${ }^{12}$ It should be stressed that Hegel's position on the duality between extensional and intensional objects may be seen as a reversal of our current 'analytic' assumptions. Whereas such extensional objects as sets would be considered by Hegel as abstract things - in the negative sense in which he often uses the word 'abstract' - intensional ascent into concepts would not be seen by him as such a 'bad' form of abstraction at all. According to the typical Hegelian doctrine, a concept is precisely the concrete aspect of a thing, providing it with unity, persistence in being, and characteristic activity and purposes, by being literally embedded in it. I am indebted to an anonymous referee for this point.

${ }^{13}$ On the structure of lexical competence, and especially on the distinction between its referential and inferential aspects, see Marconi 1995, 1997.

14 As Marconi observed, in the speculative procedure 'sentences of the form "the $t_{1}$ is the $t_{1}{ }^{\prime \prime}$ are really used to express our (possibly temporary) inability to go beyond a conceptual determination, such "going beyond" being the ratio essendi of the propositional

(C) The Author 2007. Journal compilation (C) Blackwell Publishing Ltd. 2007 
form. [...] Sentences of this form are therefore true, but trivial. In the context of a scientific book, their only point is a rhetorical one. They are there only to be superseded by a genuine conceptual advance' (Marconi 1980: 79).

15 According to H.-G. Gadamer, thus, the typically Hegelian 'speculative judgement' does not simply propose a new concept via its predicate, because the role of predicate is to deepen our implicit understanding of the meaning of the subject (see Gadamer 1971).

${ }^{16}$ Although it should be stressed that, following his neo-pragmatist semantic approach, Brandom may not find my traditional-minded intensional presentation very palatable. On this difference between my approach and Brandom's, see Berto 2005: Ch. 6.

17 'As examples, consider the inference from "Pittsburgh is to the west of Philadelphia" to "Philadelphia is to the East of Pittsburgh", the inference from "Today is Wednesday" to "Tomorrow will be Thursday", and that from "Lightning is seen now" to "Thunder will be heard soon". It is the contents of the concepts West and East that make the first a good inference, the contents of the concepts Wednesday, Thursday, Today, and Tomorrow, that make the second inference correct, and the contents of the concepts lightning and thunder, as well as the temporal concepts, that underwrite the third. Endorsing these inferences is part of grasping or mastering those concepts, quite apart from any specifically logical competence' (Brandom 1994: 97-98). It should be remarked that Findlay, too, stressed Hegel's continuous insistence on entailments and internal relations between concepts, not reducible to logical consequences of formal logic, but expressed by schemas of material inference (see e.g. Findlay 1958).

${ }^{18}$ For a presentation of the technical details of such a negation, see Berto 2006a, 2006b.

\section{Hegel's works}

\section{REFERENCES}

[References are to English translations of the following works]

$E n z=$ Werke in zwanzig Bände, hrg. von E. Moldenhauer und K.M. Michel, Bände 8-10: Enzyklopädie der der philosophischen Wissenschaften in Grundrisse. Frankfurt a.M.: Suhrkamp, 1970; tr. The Encyclopaedia Logic (with the Zusätze), by T. F. Geraets, W. A. Suchting and H. S. Harris. Hackett: Indianapolis, 1991.

Phän= Gesammelte Werke, in Verbindung mit der Deutschen Forschungsgemeinschaft, hrg. von der Rheinisch-Westfälischen Akademie der Wissenschaften, Bd. 9: Phänomenologie des Geistes. Hamburg: Meiner, 1980; tr. The Phenomenology of Spirit, by A. V. Miller. Oxford: Oxford University Press, 1977.

$W L=$ Gesammelte Werke, in Verbindung mit der Deutschen Forschungsgemeinschaft, hrg. von der Rheinisch-Westfälischen Akademie der Wissenschaften, Bd. 11: Wissenschaft der Logik. Erster Band. Die objektive Logik (1812/13). Bd. 12: Wissenschaft der Logik. Zweiter Band. Die subjektive Logik oder die Lehre vom Begriff (1816). Hamburg: Meiner, 1978-1981; tr. Hegel's Science of Logic, by A. V. Miller. New York: Humanity Books, 1998.

\section{Other works}

Barth, E. M. (1981), 'Reconstruction of Hegelian and other Idealist Logic in Germany around 1810', in W. Becker and W. K. Essler (eds.) Konzepte der Dialektik. Frankfurt a.M.: Klostermann.

Bencivenga, E. (2000), Hegel's Dialectical Logic. Oxford: Oxford University Press.

(C) The Author 2007. Journal compilation (C) Blackwell Publishing Ltd. 2007 
Berto, F. (2005), Che cos'è la dialettica hegeliana? Un'interpretazione analitica del metodo. Padova: Il Poligrafo.

- (2006a), 'Characterizing Negation to Face Dialetheism', Logique et Analyse, 195: 241-63.

- (2006b), 'Meaning, Metaphysics and Contradiction', American Philosophical Quarterly, 43: 283-97.

Birkoff, G. and von Neumann, J. (1936), 'The Logic of Quantum Mechanics', Annals of Mathematics, 37: 823-43.

Brandom, R. B. (1994), Making It Explicit. Cambridge, MA: Harvard University Press.

- (1999), 'Some Pragmatist Themes in Hegel's Idealism: Negotiation and Administration in Hegel's Account of the Structure and Content of Conceptual Norms', European Journal of Philosophy, 7: 164-89.

- (2000), Articulating Reasons. Cambridge, MA: Harvard University Press.

- (2001), 'Holism and Idealism in Hegel's Phenomenology', Hegel-Studien, 36: 57-92.

- (2002), Tales of the Mighty Dead: Historical Essays on the Metaphysics of Intentionality.

Cambridge, MA: Harvard University Press.

Bubner, R. (1980), Zur Sache der Dialektik. Stuttgart: Reclam.

_ (1990), Dialektik als Topik: Bausteine zu einer lebensweltlichen Theorie der Rationalität. Frankfurt a.M.: Suhrkamp.

Coffa, J. A. (1991), The Semantic Tradition from Kant to Carnap: to the Vienna Station. Cambridge: Cambridge University Press.

Dummett, M. (1973), Frege. Philosophy of Language. London: Duckworth.

- (1991), The Logical Basis of Metaphysics. London: Duckworth.

Dunn, J. M. (1996), 'Generalized Ortho Negation', in H. Wansing (ed.) Negation. A Notion in Focus. Berlin-New York: De Gruyter.

- (1999), 'A Comparative Study of Various Model-Theoretic Treatments of Negation: A History of Formal Negation', in D. Gabbay and H. Wansing (eds.) What is Negation? Dordrecht: Kluwer.

Findlay, J. N. (1958), Hegel: a Re-examination. London: Allen \& Unwin.

- (1981), 'Dialectics as Metabasis', in W. Becker and W. K. Essler (eds.) Konzepte der Dialektik. Frankfurt a.M.: Klostermann.

Flach, W. (1964), 'Hegels dialektische Methode', Hegel-Studien, 1: 55-64.

Frege, G. (1892), 'Über Begriff und Gegenstand', Vierteljahrsschrift für wissenschaftliche Philosophie, 16: 192-205, repr. in Kleine Schriften, Zweite Auflage. Hildesheim: Georg Olms Verlag, 1990.

Fulda, H. F. (1965), Das Problem einer Einleitung in Hegels Wissenschaft der Logik. Frankfurt a.M.: Klostermann.

(1973), 'Unzulängliche Bemerkungen zur Dialektik', in R. Heede and J. Ritter (eds.) Hegel-Bilanz. Frankfurt a.M.: Klostermann, repr. in R.-P- Horstmann (ed.) Seminar: Dialektik in der Philosophie Hegels. Frankfurt a.M.: Suhrkamp.

- (1978), 'Hegels Dialektik als Begriffsbewegung und Darstellungsweise', in R.-P. Horstmann (ed.) Seminar: Dialektik in der Philosophie Hegels. Frankfurt a.M.: Suhrkamp.

Fulda, H. F., Horstmann, R.-P. and Theunissen, M. (1980), Kritische Darstellung der Metaphysik Eine Diskussion über Hegels 'Logik'. Frankfurt a.M.: Suhrkamp.

Gadamer, H.-G. (1971), Hegels Dialektik. Tübingen: Mohr.

Goldblatt, R. I. (1974), 'Semantic Analysis of Orthologic', Journal of Philosophical Logic, 3 : 19-35.

Goodman, N. (1972), Problems and Projects. Indianapolis: Bobbs Merrill.

Henrich, D. (1967), Hegel im Kontext. Frankfurt a.M.: Suhrkamp.

(c) The Author 2007. Journal compilation ( Blackwell Publishing Ltd. 2007 
Hösle, V. (1988), Hegels System: Der Idealismus des Subjektivität und das Problem der Intersubjektivität, voll. I-II. Hamburg: Meiner.

- (2003), 'Inferenzialismo in Brandom e olismo in Hegel. Una risposta a Richard Rorty e alcune domande per Robert Brandom', in L. Ruggiu and I. Testa (eds.) Hegel contemporaneo. La ricezione americana di Hegel a confronto con la tradizione europea. Milano: Guerini.

Inwood, M. J. (1983), Hegel. London: Routledge \& Kegan Paul.

Jaeschke, W. (1979), ‘Objektives Denken. Philosophiehistorische Erwägungen zur Konzeption und zur Aktualität der spekulativen Logik', The Independent Journal of Philosophy, 3: 23-37.

Lamb, D. (1979), Language and Perception in Hegel and Wittgenstein. Avebury.

Marconi, D. (1980), Contradiction and the Language of Hegel's Dialectic: a Study of the Science of Logic, (Doctorate Thesis). Pittsburgh. University Microfilms International.

- (1995), 'On the Structure of Lexical Competence', Proceedings of the Aristotelian Society, 95: 245-61.

- (1997), Lexical Competence. Cambridge, MA: MIT Press.

McDowell, J. (1994), Mind and World. Cambridge, MA: Harvard University Press.

Mure, G. (1950), A Study of Hegel's Logic. Oxford: Clarendon.

Carnap, R. (1937), The Logical Syntax of Language. London: Routledge \& Kegan Paul.

- (1947), Meaning and Necessity. Chicago-London: University of Chicago Press.

Pinkard, T. (1994), Hegel's Phenomenology. The Sociality of Reason. Cambridge: Cambridge University Press.

Pippin, R. B. (1988), Hegel's Idealism. The Satisfactions of Self-Consciousness. Cambridge: Cambridge University Press.

Prawitz, D. (1965), Natural Deduction. A Proof-Theoretical Study. Uppsala: Almqvist \& Wilksell.

Price, H. (1990), 'Why “Not"?', Mind, 99: 221-38.

Quine, W. V. O. (1960), Word and Object. Cambridge, MA: MIT Press.

Redding, P. (1996), Hegel's Hermeneutics. Ithaca \& London: Cornell University Press.

Schnädelbach, H. (1987), 'Dialektik und Diskurs', Allgemeine Zeitschrift für Philosophie, 12: 1-23.

— (1999), Hegel zur Einführung. Hamburg: Junius Verlag.

Sellars, W. (1956), Empiricism and the Philosophy of Mind. Cambridge, MA: Harvard University Press.

Tennant, N. (1999), 'Negation, Absurdity and Contrariety', in D. Gabbay and H. Wansing (eds.) What is Negation? Dordrecht: Kluwer.

Theunissen, M. (1980), Sein und Schein. Die kritische Funktion der Hegelschen Logik. Frankfurt a.M.: Suhrkamp.

Wittgenstein, L. (1921). 'Logisch-philosophische Abhandlung', Annalen der Naturphilosophie 14 (rev. ed. Tractatus logico-philosophicus. London: Routledge \& Kegan Paul, 1922).

- (1974), Philosophical Grammar. Oxford: Blackwell.

- (2000), Big Typescript. Wien: Springer Verlag.

Wohlfahrt, G. (1981), Der spekulative Satz. Bemerkungen zum Begriff der Spekulation bei Hegel. Berlin-New York: De Gruyter.

Wolff, M. (1981), Der begriff des Widerspruchs. Eine Studie zur Dialektik Kants und Hegels. Königstein: Hain.

Yovel, Y. (1981), 'Hegel's Dictum that the Rational is Actual and the Actual is Rational. Its Ontological Content and Its Function in Discourse', in W. Becker and W. K. Essler (eds.) Konzepte der Dialektik. Frankfurt a.M.: Klostermann.

(C) The Author 2007. Journal compilation (C) Blackwell Publishing Ltd. 2007 